\title{
The Impact of Corporate Governance on Banks Profitability in Nigeria
}

\author{
http://doi.org/10.21272/fmir.5(1).18-28.2021
}

\section{Foluso Ololade Oluwole,}

Adekunle Ajasin University, Akungba Akoko, Ondo State, Nigeria

\begin{abstract}
The major concern of regulatory authority overtime is on the need to enhance sound practices among banks through the improvement of corporate governance; therefore this research examined the effect of corporate governance on commercial banks profitability in Nigeria. The study covered the period of 2009 to 2018 and secondary data were obtained from the audited financial statement of the selected banks which are Guarantee Trust Bank Nigeria PLC, Zenith Bank PLC and First Bank of Nigeria PLC. Fixed effect regression technique was used to examine the effect of Audit Committee Size (ACS), Board Size (BS), Audit Committee Number of Meeting (ACNM) and Board Number of Meeting (BNM) on earnings per share (EPS) of the selected banks. The independent variables results showed a positive and significant relationship on Earnings per share of the banks with coefficient and probability(prob.) value of the variables as follows: audit committee size $(0.6241 ; 0.0109)$, board size $(0.4349 ; 0.007)$ and board number of meeting $(0.0356)$ had positive and significant effect on earnings per share of the banks respectively. However, negative and significant relationship was established between audit committee number of meeting and earnings per share with a coefficient and probability value of -1.0781 and 0.0001 respectively. With the F-Stat. of 2.84 and a prob. of 0.025 , all the null hypotheses were rejected and the alternative hypotheses accepted, indicating that all the independent variables significantly affect the dependent variable. The study concluded that corporate governance enhances commercial banks performance in Nigeria. It therefore recommended that attention should be paid to the audit committee size, board size and board number of meetings since an increase in them leads to increase in the earnings per share while the audit committee number of meetings should be reduced as it affects the earnings per share negatively. The regulatory authority should formulate strong policy frameworks that would ensure that commercial banks constantly comply with corporate governance standard set by the authority.
\end{abstract}

Keywords: corporate governance, profitability, financial institutions, earnings per share.

JEL Classification: G30, G21, G28, G32.

Cite as: Oluwole, F. O. (2021). The Impact of Corporate Governance on Banks Profitability in Nigeria. Financial Markets, Institutions and Risks, 5(1), 18-28. http://doi.org/10.21272/fmir.5(1).18-28.2021

Received: 15 December 2020

Accepted: 18 January 2021

Published: 30 March 2021

Copyright: (C) 2021 by the author. Licensee Sumy State University, Ukraine. This article is an open access article distributed under the terms and conditions of the Creative Commons Attribution (CC BY) license (https://creativecommons.org/licenses/by/4.0/)

\section{Introduction}

Corporate governance ensures that management and board of directors comply with best and sound practices in carrying out their duties through the establishment of principles and procedures. Policy frameworks were formulated by regulatory authorities in Nigeria to ensure that commercial banks comply with corporate governance practices. However, Soludo (2004) opined that commercial banks have not been complying with regulations on corporate governance which has eroded customers' confidence in the system.

The Nigerian financial environment is being affected by governance problems, systemic instability and failure of financial institutions to comply with lending practices which has affected the growth and development of the economy. Ibitamuno, Onuchuku, \& Nteegah (2018) argued that the recent global financial crisis and erosion of commercial banks investment in Nigeria results in lack of compliance with credit management practices which is associated with poor corporate governance.

The consolidation policy of 2006 which led to reduction in commercial banks from 89 to 25 is an indication of erosion in best practices and high sharp dealings in the banking industry which resulted in liquidity crisis. 
High rate of improper accounting practices by Oceanic Bank, Intercontinental Bank, Union Bank, Afri Bank, Fin Bank and Spring Bank in 2009 and sacking of Chairman and Managing director of Skye Bank in July, 2016 for improper management of funds were indication of challenges of corporate governance in the Nigeria banking industry (Ibitamuno, et al., 2018).

Given the high rate of instability in the banking system which resulted in the takeover of some banks like Skye Bank and Intercontinental Bank and recently, Diamond Bank Plc; the major concern of regulatory authority is on the need to enhance sound practices among banks through the improvement of corporate governance. Though, studies have been conducted on corporate governance and banks performance in Nigeria, there is paucity of studies in the subject area in the recent years. Moreover, empirical studies limit their corporate governance variables to Board Size and Board Composition (Olabisi \& Omoyele, 2011; Emeka \& Alem, 2016; Ibitamuno, et al., 2018; Agbaeze \& Ogbosi, 2018). Also, Mohammed (2012) employed asset quality of bank and non- performing loan which were not appropriate to measure corporate governance. While Olayiwola (2018) employed audit committee size as important variable of corporate governance, but the study was conducted in manufacturing sector and not banking sector. Thus, this study would fill the above gap by disaggregating corporate governance into audit committee size, board size, audit committee number meetings and board number meetings and look at the effect on the banking performance. Therefore the study is aimed at evaluating and investigating the effect of audit committee size, board size, audit committee number of meetings and board number of meetings on the profitability of commercial banks in Nigeria. The hypotheses of the study are stated in the null form as follows:

$>\quad$ Audit committee size has no significant effect on commercial banks' profitability in Nigeria.

$>\quad$ Board size has no significant effect on commercial banks' profitability in Nigeria.

$>\quad$ There is no significant relationship between audit committee number of meetings and commercial banks' profitability in Nigeria.

$>\quad$ Board number of meetings has no significant effect on commercial banks' profitability in Nigeria.

\section{Empirical Review}

Olabisi and Omoyele (2011) investigated the relationship between corporate governance and the performance of banks in Nigeria. Statistical Package for Social Scientist (SPSS) was used to analyze the data collected and it was revealed that lack of proper corporate governance is the bane of so many banks in Nigeria. The collapse and failure of many banks was as a result of both poor audit control and directors' negligence to observe due diligence and acceptable standard practices.

Mohammed (2012) examined the impact of corporate governance on the performance of banks in Nigeria from 2001 to 2010. Data were analyzed using multiple regression analysis and the study showed that poor asset quality defined as the ratio of non-performing loan to credit and loan deposit ratios negatively affect financial performance and vice visa.

Ajala, Amuda and Arulogun (2012) examined the effects of corporate governance on the performance of Nigerian banking sector with the aim of assessing the impact of corporate governance on firm's performance using secondary source of data The Pearson Correlation and the regression was used for data analysis The study revealed that a negative but significant relationship exists between board size and the financial performance of these banks while a positive and significant relationship was also observed between directors' equity interest, level of corporate governance disclosure index and performance of the sampled banks.

Adeusi, et al, (2013) in their work on Corporate Governance and Firm Financial Performance used a sample of 10 selected banks' annual reports covering 2005-2010 to examine the relationship between corporate governance and performance in Nigeria banking sector. The result of the panel regression indicated that improved performance of the banking sector is not dependent on increasing the number of executive directors and board composition.

Utilizing the regression method, Ammar et al (2013) from a sample of 160 firms in the Karachi Stock Exchange (KSE) for periods 2007 to 2011 gathered that there exist a positive association between board size and firm performance while a negative relationship existed between non-executive directors' percentage, chief executive officer duality and performance. 
Al-Moataz and Hussainey (2013) analyzed 52 Saudi companies for the years 2006-2007. Dependent variable was corporate governance disclosure score (zero for non-compliance and nine for full compliance); firm profitability (ROA), firm liquidity (current ratio), firm debt ratio, firm size (total assets), board independence, and audit committee size were independent variables. The study found that board independence was negatively significant; audit committee size and firm profitability (ROA) and firm liquidity were positively significant, whereas firm size was not positively significant for corporate governance.

Danoshana and Ravivathani (2013) investigated the effect of governance practices on the performance of 25 Sri Lankan financial institutions taking a data period of 2008-2012. They concluded that corporate governance practices have an impact on the performance of the financial institutions.

Basuony, Mohamed and Al-Baidhani (2014) accessed the effect of internal corporate governance mechanisms and control variables, such as bank size and bank age on bank financial performance. Ordinary least square technique was used to test the effect of corporate governance mechanisms on bank financial performance. The results of this study reveal that there is a significant relationship between corporate governance and bank profitability.

Akingunola, Adedipe and Olusegun (2015) examined corporate governance and bank's performance in Nigeria. They employed the ordinary least squares regression method to analyze their data and their result shows that Bank deposits mobilized and credits created over these period increased over the years but were more positively related to bank performance during the period of consolidation although not significant.

Xavier, Shukla, Oduor and Mbabazize (2015) investigated the effect of corporate governance on financial performance of commercial banks in Rwanda. The study adopted a descriptive research design and it was concluded that there is no significant relationship between corporate governance and financial performance

Emeka and Alem (2016) empirically investigated the effect of corporate governance on bank's financial performance in Nigeria from 2003 to 2014 using the ordinary least square regression technique. The study revealed that the relationship between corporate governance and bank performance in Nigeria is quite significant as a unit change in the board size and the relative size of non-executive directors increases the return on assets.

Buallay, Hamdan and Zureigat (2017) used corporate governance practices as the independent variable, the firm performance (ROA, ROE, Tobin's Q) as the dependent variable and five control variable which are firm size, firm age, auditing quality, board size, and an industry dummy, to find the impact of governance practice on the performance from year 2012 to 2014. They found corporate governance, largest shareholder's ownership and independence of the board had no significant effect on firm performance while f ownership structure and board size had significant effect on the firm performance was found.

Agbaeze and Ogosi (2018) examined the impact of corporate governance on profitability of Nigerian banks for the period 2005 to 2015. The ex-post facto research design was adopted and the correction and regression test statistic was used to for data analysis. The study concluded that corporate governance had positive impact on profitability of Nigerian banks.

Ibitamuno et al, (2018) studied the effect of corporate governance on the performance of banks in Nigeria over the period 2012 and 2016 analyzed using panel technique. It was revealed that corporate governance had less implication on the performance of banks in Nigeria.

Olayiwola (2018) assessed the influence of corporate governance on the performance of companies using panel data regression method for the data analysis and it was found that board size had significant and negative effect net profit margin, board composition had a significant positive correlation with NPM, audit committee size had an insignificant correlation with NPM and board size, board composition and audit committee size had a significant joint effect on NPM.

Using panel regression technique, Ghalid (2018) explored the effectiveness of good corporate governance on banks performance in Indonesia It was revealed in the study that good corporate governance is the most widely significant determinant of bank profitability.

Almoneef and Samontaray (2019) examined the impact of corporate governance on the Saudi banking performance for the period of 2014 and 2017 using panel data analysis with both descriptive and multivariate 
analysis through multiple regression and the results showed that board size, audit committee meeting and bank size had a positive impact on ROE, whereas board independence had negative impact on ROE.

From the reviewed Studies on the effect of corporate governance on banks performance in Nigeria; studies limit their corporate governance variables to Board Size and Board Composition (Olabisi \& Omoyele, 2011; Emeka \& Alem, 2016; Ibitamuno, et al., 2018; Agbaeze \& Ogbosi, 2018). Also, Mohammed (2012) employed asset quality of bank and non- performing loan which were not appropriate to measure corporate governance. While Olayiwola (2018) employed audit committee size as important variable of corporate governance, but the study was conducted in manufacturing sector and not banking sector. Thus, this study would fill the above gap by disaggregating corporate governance into audit committee size, board size, audit committee number meetings and board number meetings for adequate and robust analysis.

\section{Methods}

2.1 Research Design. The researcher adopted the ex post facto design which involves the collection of historical data from secondary sources and analyzing the relationship among variables using econometric techniques.

2.2 Sampling Technique. Sample of three commercial banks were randomly selected base on the availability of financial statement.

2.3 Sources of Data. Data were obtained from financial statement of commercial banks from 2009 to 2018. These firms include Zenith Bank of Nigeria PLC., First Bank of Nigeria PLC, Guarantee Trust Banks PLC. These banks are selected because they are part of the big players in the Nigeria banking system.

2.4 Model Specification. For the purpose of evaluating the effect of corporate governance on commercial banks' profitability in Nigeria, panel multiple regression model be formulated. This study adapted the model of Olayiwola (2018) as follow:

$E P S=f(A C S, B S, A C N M, B N M)$

$E P S_{i t}=\beta_{0}+\beta_{1} A C S_{i t}+\beta_{2} B S_{i t}+\beta_{3} A C B M_{i t}+\beta_{4} B N M_{i t}+e_{1 i}$

Where:

$E P S=$ Earnings per Share;

$A C S=$ Audit Committee Size;

$B S=$ Board Size;

$A C N M=$ Audit Committee Number of Meetings;

$B N M=$ Board Number of Meetings;

$\beta_{0}=$ Constant Term;

$\beta_{1}-\beta_{4}=$ Parameters;

$i=$ Individual Firm;

$e=$ error term.

2.5 Estimation Methods. The choice of estimation will depend on the specification of model, the nature of the available data and the purpose of the model. For the purpose of validating the hypotheses stated, this study adopted the Panel Multiple Regression analysis evaluation technique. This is because it allows the unobservable heterogeneity for each observation in the sample to be eliminated and multicollinearity among variables to be alleviated. However, based on the outcome of the Hausman tests, fixed effect regression model was employed to examine the effect of corporate governance on predominance of commercial banks in Nigeria.

2.6 Description of Variables. Earnings per Share = Profit after tax divided by number of equity.

Audit Committee Size $=$ Numbers of audit committee

Board Size $=$ Numbers of board size which comprises of both executive and non executive directors.

Audit Committee Number of Meetings $=$ Numbers of times audit committee members meet in a year.

Board Number of Meetings $=$ Numbers of times board members meet in a year. 


\section{Results}

\subsection{Descriptive Statistic}

Table 1. Descriptive Statistic

\begin{tabular}{|l|c|c|c|c|c|}
\hline & EPS & BS & ACS & ACNM & BNM \\
\hline Mean & 3.635667 & 13.20000 & 5.666667 & 4.100000 & 6.233333 \\
\hline Maximum & 3.050000 & 13.00000 & 6.000000 & 4.000000 & 5.500000 \\
\hline Minimum & 9.800000 & 16.00000 & 7.000000 & 7.000000 & 12.00000 \\
\hline Std. Dev. & 0.600000 & 10.00000 & 3.000000 & 2.000000 & 4.000000 \\
\hline Skewness & 2.280896 & 1.882771 & 1.028334 & 1.093870 & 2.402346 \\
\hline Kurtosis & 1.113148 & 0.147560 & -1.813296 & 0.604513 & 1.268514 \\
\hline Jarque-Bera & 6.593924 & 1.720370 & 23.06686 & 7.234975 & 8.920286 \\
\hline Probability & 0.036995 & 0.423084 & 0.000010 & 0.026850 & 0.011561 \\
\hline Observations & 30 & 30 & 30 & 30 & 30 \\
\hline
\end{tabular}

Source: Researcher's Computation, 2019.

The result of the descriptive statistics is presented in Table 1. The result shows that the variables have low mean values with small standard deviation from the mean value. The result indicates that while audit committee size is negatively skewed, earnings per share, board size, audit committee number of meetings and board number of meetings are positively skewed. Furthermore, the result reveals that earnings per share and board number of meetings are mesokurtic since their kurtosis value are not close to three. Board size is platykurtic while audit committee number of meetings and board number of meetings are leptokurtic.

\subsection{Correlation Matrix}

Table 2. Correlation Matrix

\begin{tabular}{|l|c|c|c|c|c|}
\hline & EPS & ACS & BS & ACNM & BNM \\
\hline EPS & 1.000000 & & & & \\
\hline ACS & 0.046702 & 1.000000 & & & \\
\hline BS & 0.501502 & -0.195913 & 1.000000 & & \\
\hline ACNM & -0.478156 & 0.122620 & -0.529085 & 1.000000 & 1.000000 \\
\hline BNM & 0.528429 & -0.051180 & 0.286653 & -0.402846 & \\
\hline
\end{tabular}

Source: Researcher's Computation, 2019.

Table 2, which presents the correlation matrix of the variables, employed indicates the absence of multi colinearity since the variables are not perfectly co-linear and have correlation values that are less than 0.7. However, the result indicates that audit committee size, board size, and board number of meetings are positively correlated with earnings per share while audit committee number of meetings is negatively correlated with earnings per share.

\subsection{Panel Data Analysis}

Table 3. Pooled Regression Analysis

\begin{tabular}{|l|c|c|c|c|}
\hline Variable & Coefficient & Std. Error & t-Statistic & Prob. \\
\hline ACS & 0.337506 & 0.334772 & 1.008166 & 0.3230 \\
\hline BS & 0.405672 & 0.214814 & 1.888479 & 0.0706 \\
\hline ACNM & -0.354197 & 0.382396 & -0.926257 & 0.3632 \\
\hline BNM & 0.353002 & 0.154185 & 2.289466 & 0.0308 \\
\hline C & -4.379908 & 4.596411 & -0.952897 & 0.3498 \\
\hline R-squared & 0.752732 & & \\
\hline Adjusted R-squared & 0.665169 & & \\
\hline F-statistic & 5.170362 & \\
Prob(F-statistic) & 0.003556 & & \\
\hline Durbin-Watson stat & 1.715406 &
\end{tabular}

Source: Researcher's Computation, 2019.

Table 3 presents panel least square result on the effect of audit committee size, board size, audit committee number of meetings and board number of meetings on earnings per share of commercial banks in Nigeria. The result indicates that board size has positive and insignificant effect on earnings per share. Also, the result reveals that account committee size has positive and insignificant effect on earnings. However, audit 
committee number of meetings has negative and insignificant effect on earnings per share. Finally, board size had positive and significant effect on earnings per share as reported in Table 3.

\subsection{Hausman Test}

Table 4. Hausman Test

\begin{tabular}{|l|l|l|l|}
\hline Test Summary & Chi-Sq. Statistic & Chi-Sq. d.f. & Prob. \\
\hline Cross-section random & 10.980223 & 4 & 0.0268 \\
\hline
\end{tabular}

Source: Researcher's Computation, 2019.

Table 4 presents the Husman Test result to select the appropriate model between fixed and random effect. The result shows that the chi-square probability value at 4 degree of freedom is given as 0.0268 which is significant at 5\%. Thus, the null hypothesis that random effect model produce a better estimate is rejected which implies fixed effect model produce satisfactory and reliable result than random effect model. Fixed effect model produce is thus reported and used for hypothesis testing.

\subsection{Fixed Effect Model Result}

Table 5. Fixed Effect Model

\begin{tabular}{|l|l|l|l|l|}
\hline Variable & Coefficient & Std. Error & t-Statistic & Prob. \\
\hline ACS & 0.624127 & 0.216788 & 2.878979 & 0.0109 \\
\hline BS & 0.434874 & 0.184092 & 2.819065 & 0.0077 \\
\hline ACNM & -1.078152 & 0.214135 & -5.034917 & 0.0001 \\
\hline BNM & 0.356760 & 0.101145 & 3.527214 & 0.0028 \\
\hline C & -2.124774 & 3.909846 & -0.543442 & 0.5943 \\
\hline R-squared & 0.797697 & & \\
\hline Adjusted R-squared & 0.752076 & & \\
\hline F-statistic & Prob(F-statistic) & \multicolumn{5}{l}{} & \\
\hline Durbin-Watson stat & \multicolumn{5}{l}{} & & \\
\hline
\end{tabular}

Source: Researcher's Computation, 2019.

The fixed effect result is presented in table 4.5. The result indicates that audit committee size has positive and significant effect on earnings per share with a coefficient of 0.624127 which implies that 1 unit increase in audit committee size will lead to 0.624127 increases in earnings per share in Nigeria.

Similarly, the result indicates that board size has a coefficient of 0.434874 which is significant at $5 \%$ indicating that a unit increase in board size will lead to 0.434874 increases in earnings per share of the selected commercial banks in Nigeria.

Conversely, it is found that audit committee number of meetings has negative and significant effect on earnings per share with coefficient of -1.078152 such that a unit increase in audit committee number of meetings will lead to -1.078152 fall in earnings per share. Finally, board number of meetings has a coefficient of 0.356760 which is significant at $5 \%$. This implies that a unit increase in board number of meetings will lead to 0.356760 increases in share price.

The coefficient of determination is use to check the explanatory power of the independent variables. The Adjusted R-squared of 0.752076 implies that $75 \%$ of changes in earnings per share is explained by movement of audit committee size, board size, audit committee number of meetings and board number of meetings. The result shows that Durbin-Watson statistic has a value of 1.655010 which is close to 2 and with the acceptance region of $1.5-2.5$. This implies that there is absence of autocorrelation in the residuals of the model. This study employs F-statistic to test the overall significance of audit committee size, board size, audit committee number of meetings and board number of meetings on earnings per share. The F-statistic value is given as 2.840541 with a probability value of 0.025374 which is significant at $5 \%$, thus it is concluded that audit committee size, board size, audit committee number of meetings and board number of meetings significantly influence earnings per share.

The result of the fixed effect regression reported in table 4.5 shows that audit committee size has a statistic value of 2.878979 and probability value of 0.0109 which is significant at $5 \%$ which lead to the rejection of the null hypothesis that Audit committee size has no significant effect on commercial banks' profitability in Nigeria. 
The result also indicates that board size has a statistical significant effect on earnings per share with a t-statistic and probability value of 0.434874 and 0.0077 respectively. Thus, the null hypothesis that board size has no significant effect on commercial banks' profitability in Nigeria is rejected.

Furthermore, audit committee number of meetings has a t-statistic value of -5.034917 with a corresponding probability value of 0.0001 which is significant $5 \%$ leading to the rejection of the null hypothesis that there is no significant relationship between audit committee number of meetings and commercial banks' profitability in Nigeria.

Finally, board number of meetings has a statistical significant effect on earnings per share with a t-statistic and probability value of 3.527214 and 0.0028 respectively which is significant at $5 \%$. Thus, the null hypothesis that board number of meetings has no significant effect on commercial banks' profitability in Nigeria is rejected.

3.6. Discussion of Findings. This research looks into the effect of corporate governance on commercial banks' profitability in Nigeria. It is found that audit committee size has positive and significant effect on earnings per share of commercial banks in Nigeria. This result is not supported by the findings of Almoneef and Samontaray (2019)

Also, it is revealed that board size has positive and significant effect on earnings per share of selected commercial banks in Nigeria. This result contradicts the findings of Ene and Bello (2016); Ibitamuno, et al., (2018) who established negative relationship between board size and financial performance of commercial banks but conforms to the findings of Agbaeze and Ogosi (2018).

On the contrary, it is embellished that audit committee number of meetings has negative and significant effect on commercial banks performance in Nigeria which conforms to the findings of Basuony, et al., (2014) but not in line with the empirical finings of Almoneef and Samontaray (2019). Finally, the study indicates that board number of meetings has positive and significant effect on earnings per share of selected commercial banks in Nigeria which conforms to the result of Olayiwola (2018). The implication of these findings is that corporate governance plays significant role in enhancing financial performance of commercial banks in Nigeria.

\section{Conclusion and Recommendations}

Corporate governance plays important role in the management of large organization. This is because firms are not only answerable to shareholders but also to other stakeholders. Thus, corporate governance exists to balance the dealings of an organization with shareholders and other stakeholders. Thus, this study investigated the effect of audit committee size, board size, audit committee number of meetings and board number of meetings on the profitability of commercial banks in Nigeria. The study concluded that, corporate governance enhances commercial banks performance in Nigeria.

1. Managers and board of directors should pay attention the audit committee size, board size and board number of meetings since an increase in them leads to increase in the earnings per share while the audit committee number of meetings should be reduced as it affects the earnings per share negatively. They should adopt high standard corporate governance in order to continuously maintain efficiency and sustainability in commercial banks operations.

2. Regulatory authority should formulate strong policy frameworks that would ensure that commercial banks constantly comply with corporate governance standard set by the authority.

3. There is need to ensure that board of directors are not only after enhancing shareholders value but also seek after promoting the interest of other stakeholders like depositors, community members, government. This can be achieved by set up independent committee by regulatory authority to check mate the activities of board of director.

\section{References}

1. Adeusi S, Akeke N, Aribaba F, \& Adebisi O. (2013). Corporate governance and firm financial performance: Do ownership and board size matter. Academic Journal of Interdisciplinary Studies 2, 251258. Retrieved from: https://www.mcser.org/journal/index.php/ajis/article/view/1411 
2. Agbaeze, E.K \& Ogosi, C.D (2018). Corporate governance and profitability of Nigerian banks. European Journal of Scientific Research, 148(3), 358-367. Retrieved from: https://www.europeanjournalofscienti ficresearch.com/issues/PDF/EJSR $148 \quad 3$ 05.pdf

3. Ahmed, E. \& Hamdan, A. (2015). The effect of corporate governance on firm performance: Evidence from Bahrain Exchange. European Journal of Business and Innovation Research, 3(5), 25 - 48

4. Ajala, O. A., Amuda, T. \& Arulogun, L. (2012). Evaluating the effects of corporate governance on the performance of Nigerian banking sector. Review of Contemporary Business Research, 1(1), 32-42. Retrieved from: http://rcbrnet.com/journals/rcbr/Vol_1_No_1_December_2012/4.pdf

5. Akingunola R.O, Adekunle O.A \&Adedipe O.A. (2015). Corporate governance and bank's performance in Nigeria. European Journal of Business and Social Sciences, 2(8), 89-111. Retrieved from: https://ir.unilag.edu.ng/bitstream/handle/123456789/3976/Corporate\%20\%20Governance\%20\%20Practi ces $\% 20 \% 20$ and $\% 20 \% 20$ Banks.pdf? sequence $=1 \&$ is Allowed $=y$

6. Allen, F. \& Gale, G. (2000). Comparing financial systems. Cambridge: MIT Press Massachusetts. Retrieved from: https://mitpress.mit.edu/books/comparing-financial-systems

7. Al-Moataz, E., \& Hussainey, K. (2013). Determinants of corporate governance disclosure in Saudi Corporations. JKAU: Econ. \& Adm., 27(2), 411-430. Retrieved from: https://www.kau. edu.sa/Files/1001002/Researches/66403 37943.pdf

8. Almoneef, A \& Samontaray, P.D (2019). Corporate governance and firm performance in the Saudi banking industry. Banks and Bank Systems, 14(1), 147-158. http://dx.doi.org/10.21511/bbs.14(1).2019.13

9. Ammar, A. G, Saeed, A. \& Abid, A. (2013). Corporate governance and performance: empirical evidence from textile sector of Pakistan. African Journal of Business Management, 7(22), 2112 - 2118. Retrieved from: https://academicjournals.org/article/article1380698681_Ammar\%20et\%20al.pdf

10. Andrew, B. (2015). Three pillars of corporate sustainability. Retrieved from: http://www.investopedia.com/articles/investing/100515/three-pillars-corporatesustainability

11. Anthony, K. C. (2007). Corporate governance and firm performance in Africa: A dynamic panel data analysis. A Paper presented for the International Conference on Corporate Governance in Emerging Markets. Organised By The Global Corporate Governance Forum (GCGF) And Asian Institute Of Corporate Governance (AICG), 15th - 17th, 2007, Sabanci University, Istanbul, Turkey. Retrieved from: https://onlinelibrary.wiley.com/doi/abs/10.1111/j.1813-6982.2006.00097.x

12. Basel Committee on Banking Supervision, and Bank for International Settlements, (2004). International convergence of capital measurement and capital standards: a revised framework. Basel Committee on Banking Supervision. Retrieved from: https://www.bis.org/publ/bcbs128.htm

13. Basuony, A.M, Mohamed, A.K.E \& Al-Baidhani M.A (2014). The effect of corporate governance on bank financial performance: Evidence from the Arabian Peninsula. Corporate Ownership \& Control, 11(2), 178-191. https://www.virtusinterpress.org/IMG/pdf/10-22495cocv11i2c1p3.pdf

14. Becht, M., Bolton, P. \& Röell, A. (2002). Corporate governance and control. (NBER Working Paper No. 9371). https://econpapers.repec.org/paper/nbrnberwo/9371.htm

15. Beiner, S., Drobetz, W., Schmid, F. \& Zimmerman, H. (2003). Is board size independent corporate governance mechanism? National Centre of Competitive Research and Financial Valuation and Risk Management Working Paper. Retrieved from: www.nccr-finrisk.uzh.ch/media/pdf/wp/WP089 8.pdf

16. Buallay, A., Hamdan, A. \& Zureigat, Q. (2017). Corporate governance and firm performance: Evidence from Saudi Arabia. Australasian Accounting, Business and Finance Journal, 11(1), 78-98. Retrieved from: https://ro.uow.edu.au/aabfj/vol11/iss1/5/

17. Bussoli, C. (2013). Corporate governance and bank performance in Italy. Financial Systems in Troubled Waters: Information, Strategies, and Governance to Enhance Performances in Risky Times, 40. Retrieved from: https://www.virtusinterpress.org/IMG/pdf/Corporate Governance and Performance in Italian Banking_Groups_by_Giulia_Romano_Paola_Ferretti_Alessandra_Rigolini.pdf

18. Calabrese, A., Costa, R., Menichini, T., Rosati, F. \& Sanfelice, G. (2013). Turning corporate social responsibility-driven opportunities in competitive advantages: A two-dimensional Model. Knowledge and Process Management, 20(1), 50-58. Retrieved from: https://onlinelibrary.wiley.com/ doi/abs $/ 10.1002 / \mathrm{kpm} .1401$

19. Clarke, T. (2004). Theories of corporate governance: Oxon: Routledge. Retrieved from: https://www.routledge.com/Theories-of-Corporate-Governance/Clarke/p/book/9780415323079

20. Coleman, K. (2008). Corporate governance and firm performance in Africa: A dynamic panel data analysis. Studies in Economics and Econometrics, 19(2), 350-367. Retrieved from: 
https://www.semanticscholar.org/paper/Corporate-governance-and-firm-performance-in-a-dataKyereboah-Coleman/14ae1ccbacaced1dce3c9003b61e3f73

21. Danoshana, S., \& Ravivathani, T. (2013). The impact of the corporate governance on firm performance: A study on financial institutions in Sri Lanka. Merit Research Journal of Accounting, Auditing, Economics and Finance, 1(6), 118-121. Retrieved from: https://meritresearchjournals.org/aaef/Content/2013/ December/Danoshana\%20and\%20Ravivathani.pdf

22. Dar, L. A., Naseem, M. A. Rehman, R. U. \& Niazi, G. S. K. (2011). Corporate governance and firm performance: A case study of Pakistan Oil and Gas Companies listed in Karachi Sick Exchange. Global Journal of Management and Business Research, 11(8). Retrieved from: https://www.journalofbusiness.org/index.php/GJMBR/article/view/527

23. Davis, J.H., Schoorman, F.D. \& Donald, L. (1997). Towards a stewardship theory of management. Academy of Management Review, 22(1), 20-34. Retrieved from: https://journals.aom.org/ doi/abs/10.5465/amr.1997.9707180258

24. Donaldson, L. \& Davis, J.H. (1991). Stewardship theory or agency theory: CEO governance and shareholder returns. Australian Journal of Management, 16(1), 49-64. Retrieved from: http://faculty.wwu.edu/dunnc3/rprnts.stewardshiporagency.pdf

25. Donaldson, L. \& Davis, J.H. (2003). Board and companies performance-research challenges and the conventional wisdom, corporate governance: An International Review, 2(3), 60-151. Retrieved from: https://onlinelibrary.wiley.com/doi/abs/10.1111/j.1467-8683.1994.tb00071.x

26. Effiok, S. O., Effiong, C., \& Usoro, A. A. (2012). Corporate governance, corporate strategy and corporate performance: Evidence from the financial institutions listed on the Nigerian Stock Exchange. European Journal of Business and Management, 4(18), 84-95. Retrieved from: https://www.iiste. org/Journals/index.php/EJBM/article/view/3226

27. Emeka, E.E \& Alem, I.E.B (2016). The effect of corporate governance on bank's financial performance in Nigeria. IOSR Journal of Business and Management, 18(11), 99-107. Retrieved from: http://www.iosrjournals.org/iosr-jbm/papers/Vol18-issue11/Version-3/M18110399107.pdf

28. Fama, E.F. \& Jensen, M. (1983). Separation of ownership and control. Journal of Law and Economics, 26, 301-325. Retrieved from: https://www.jstor.org/stable/725104

29. Filatotcher, I. \& Wright, M. (2011). Agency perspectives on corporate governance of multination enterprise. Journal of Management Studies, 48(2), 471-486. Retrieved from: https://onlinelibrary.wiley.com/doi/full/10.1111/j.1467-6486.2010.00921.x

30. Ghalib, S. (2018). Good corporate governance rating and bank profitability in Indonesia: Evidence from panel data. International Journal of Business and Society, 19 (3), 570-586. Retrieved from: http://www.ijbs.unimas.my/index.php/content-abstract/all-issues/63-vol-19-no-3-2018/503-goodcorporate-governance-rating-and-bank-profitability-in-indonesia-evidence-from-panel-data

31. Ghalid, S. (2018). Good corporate governance rating and bank profitability in Indonesia: Evidence from panel data. International Journal of Business and Society, 19(3), 570-586. Retrieved from: http://www.ijbs.unimas.my/index.php/content-abstract/all-issues/63-vol-19-no-3-2018/503-goodcorporate-governance-rating-and-bank-profitability-in-indonesia-evidence-from-panel-data

32. Heremans, D. (2007). Corporate governance issues for banks: A financial stability perspective. Working Paper. Retrieved from: https://core.ac.uk/download/pdf/6978897.pdf

33. Hermalin, B. \& Wezbach, B. (2001). The effect of board composition and direct incentives on firm performance. Financial Management, 20(4), 101-112. Retrieved from: https://ideas.repec.org/a/fma/fmanag/hermalin91.html

34. Hitt, M., Ireland, R.D. \& Hoskisson, R. (2012). Strategic management laws: Competitiveness globalization. Boulevard: Engage, Learning. Retrieved from: http://www.microlinkcolleges.net/ elib/files/postgraduate/Master\%20of\%20Business $\% 20$ Administration/strategic $\% 20$ management $\% 20$ con cepts.pdf

35. Ibitamuno, A.D, Onuchuku O \& Nteegah, A. (2018). Corporate governance and banking sector performance in Nigeria. Journal of Applied Economics and Business, 6(4), 35-50. Retrieved from: http://www.aebjournal.org/articles/0604/060403.pdf

36. International Finance Corporation. (2004). The Russia corporate governance manual: Corporate governance introduced. Alpina Business Books, Moscow. Retrieved from: 
Financial Markets, Institutions and Risks, Volume 5, Issue 1, 2021 ISSN (online) - 2521-1242 ISSN (print) - 2521-1250

https://www.ifc.org/wps/wcm/connect/5ea2b35e-a475-43be-a7a4-e7df49fb2a9e/CG Manual Russian Eng.pdf?MOD=AJPERES\&CVID=kiUrgcy

37. Jensen, M. \& Meckling, W. (1976). Theory of the firm: Managerial behavior, agency costs and ownership structure. Cambridge University Press. Retrieved from: https://josephmahoney.web.illinois.edu/ BA549 Fall\%202012/Session\%205/5 Jensen Meckling\%20(1976).pdf

38. Johnson, G., Scholes, K. \& Whittington, R. (2008). Exploring corporate strategy. England: Pearson Education Limited, Essex. Retrieved from: http://www.mim.ac.mw/books/Johnson\%20and\% 20Scholes $\% 20$ Exploring\%20Corporate $\% 20$ Strategy, $\% 20$ Text $\% 20$ and $\% 20$ Cases.pdf

39. Kolk, A., \& Pinkse, J. (2010). The integration of corporate governance in corporate social responsibility disclosures. Corporate Social Responsibility and Environmental Management, 17(1), 15-26. Retrieved from: https://onlinelibrary.wiley.com/doi/abs/10.1002/csr.196

40. Mason, E.S. (1960). The Meaning of Modern Business: An Introduction to the Philosophy of Large Corporate Enterprise. The ANNALS of the American Academy of Political and Social Science, 33(1), 167168. Retrieved from: https://www.worldcat.org/title/meaning-of-modern-business-an-introduction-to-thephilosophy-of-large-corporate-enterprise/oclc/231285

41. Mohamed, S., Ahmad, K. \& Khai, K. (2016). Corporate governance practices and firm performance: Evidence from top 100 public listed companies in Malaysia. Procedia Economics and Finance, 35, $287-$ 296. Retrieved from: https://www.sciencedirect.com/science/article/pii/S2212567116000368

42. Mohammed, F. (2012). Impact of corporate governance on banks performance in Nigeria. Journal of Emerging Trends in Economics and Management Sciences, 3(3), 257-260. Retrieved from: https://citeseerx.ist.psu.edu/viewdoc/download?doi=10.1.1.300.9453\&rep=rep1\&type=pdf

43. Muth, M. M, \& Donaldson, L. (1998). Stewardship theory and board structure: A contingency approach. Corporate Governance: An International Review, 6(1), 5-28. Retrieved from: https://econpapers.repec.org/RePEc:bla:corgov:v:6:y:1998:i:1:p:5-28

44. Nmehielle, V.O. \& Nwauche, E.S. (2004). External-internal standards in corporate governance in Nigeria. Public Law and Legal Theory Working Paper NO. 115, George Washington University Law School. Retrieved from: http://www.sciepub.com/reference/284099

45. Odiwo, W. O., Chukwuma, C. S. \& Kifordu, A. A. (2013). The impact of corporate governance on the performance of manufacturing firms in Nigeria. International Journal of Science and Research, 5(9), 924 - 933. Retrieved from: https://www.ijsr.net/archive/v5i9/ART20161412.pdf

46. Ogbechie, C. \& Koufopoulos, D, N. (2007). Corporate governance practices in publicly quoted companies in Nigeria. presented at the 4th World Congress on Corporate Governance jointly sponsored by the Management of Innovation and New Technology (MINT) Research Centre, the Directors College and the DeGroote School of Business, McMaster University, Hamilton, Ontario, Canada, January 24-26. Retrieved from: https://ideas.repec.org/a/ids/ijbget/v3y2007i4p350-381.html

47. Ogbechie, C. (2006). Corporate governance: A challenge for Nigerian banks. Retrieved from: https://www.ajol.info/index.php/epr/article/view/39246

48. Ogunbunka, N.M. (2002). Risk and internal control management in financial institutions. Lagos, Nigeria: The Chartered Institute of Bankers of Nigeria. Retrieved from: http://mail.cibng.org/cb bookonline. asp? $\mathrm{x}$ isn $=978363660 \&$ idcat $=1$

49. Olabisi, J \& Omoyele, O. (2011). Corporate governance and the performance of Nigerian banking sector. International Journal of Development and Management Review, 6, 72-84. Retrieved from: https://www.ajol.info/index.php/ijdmr/article/view/66985

50. Olayiwola, K.T (2018). The effect of corporate governance on financial performance of listed companies in Nigeria. European Journal of Accounting, Auditing and Finance Research, 6(9), 85-98. Retrieved from: https://www.eajournals.org/wp-content/uploads/The-Effect-of-Corporate-Governance-on-FinancialPerformance-of-Listed-Companies-in-Nigeria.pdf

51. Olumuyiwa, Y.\& Babalola, Y. A. (2012). Impact of corporate governance on capital structure decision of Nigerian Firms. Research Journal in Organizational Psychology and Educational Studies, 1(2), 121 - 128. Retrieved from: https://www.academia.edu/4018022/THE IMPACT OF CORPORATE GOVERNA NCE ON CAPITAL STRUCTURE DECISION OF NIGRIAN FIRMS

52. Pandey, I.M. (2006). Financial management. India: Vikas Publishing House R.T Ltd. Retrieved from: https://ru.scribd.com/document/427578457/Pandey-I-Financial-Management-11ed-2018-pdf

53. Rimon, E., Aiman R. \& Sandy, K. (2014). The effect of corporate governance on firm performance: Evidence from Egypt. Asian Economic and Financial Review, 4(12), 1865-1877 Retrieved from: https://ideas.repec.org/a/asi/aeafrj/2014p1865-1877.html 
54. Romano, G., Ferretti, P. \& Quirici, M.C. (2012). Corporate governance and efficiency of Italian bank holding Companies during the financial crisis: an empirical analysis. Virtusinterpress Sumy, 98, 128-140. Retrieved from: https://www.virtusinterpress.org/IMG/pdf/Corporate_Governance_and_Performance_in Italian_Banking_Groups by Giulia_Romano_Paola_Ferretti_Alessandra_Rigolini.pdf

55. Sanda, A., Mikailu, S. A., \& Garba, T. (2011). Corporate governance mechanisms and firm performance in Nigeria. Nairobi: African Economic Research Consortium (AERC) Research Paper 149, AERC. Retrieved from: http://opendocs.ids.ac.uk/opendocs/bitstream/handle/123456789/ 2258/RP\%20149.pdf ?sequence $=1$

56. Shungu, P., Ngirande, H. \& Ndlovu, G. (2014). Impact of corporate governance on the performance of commercial banks in Zimbabwe. Mediterranean Journal of Social Sciences, 5(15), 93 - 105. Retrieved from: https://www.mcser.org/journal/index.php/mjss/article/view/3211

57. Soludo, C.C. (2004). Consolidating the Nigerian banking industry to meet the development challenges of the 21st century. Being an Address to the Special Meeting of Bankers Committee, Held on July 6. Retrieved from: https://www.scirp.org/(S(351jmbntvnsjtlaadkposzje))/reference/ReferencesPapers.aspx? ReferenceID $=2056738$

58. Sundaram, A.K. \& Inkpen, A.C. (2004). The corporate objective revisited. Organization Science, 15(3), 350-363. Retrieved from: https://pubsonline.informs.org/doi/abs/10.1287/orsc.1040.0068

59. Tirole, J. (2006). The theory of corporate finance. New Jersey: Princeton University Press. Retrieved from:

60. Tricker, B. (2012). Corporate governance: Principles, politics and practices. (2nd edition). Oxford: Oxford University press. Retrieved from: http://www.library.fa.ru/files/tirole-theory-corporate.pdf

61. Wan, F., Wan, Y. \& Idris, A. A. (2012). Corporate governance and firm performance of listed companies in Malaysia. Trends and Development in Management Studies, 1. 43-65. Retrieved from: http://jyotiacademicpress.net/corporate_governance_and_firm.pdf

62. Williamson, O.E. (1957). Markets and hierarchies: Analysis and antitrust implication. New York: The Free Press. Retrieved from: https://www.oxfordhandbooks.com/view/10.1093/oxfordhb/9780199646135.001. 0001/oxfordhb-9780199646135-e-12

63. Xavier, S.M., Shukla, J., Oduor J \& Mbabazize, M. (2015). Effect of corporate governance on the financial performance of banking industry in Rwanda: A case study-commercial banks in Rwanda. International Journal of Small Business and Entrepreneurship Research, 3(6), 29-43. Retrieved from: http://erepo.usiu.ac.ke/bitstream/handle/11732/3364/CHRISTELLE\%20GATCHERIMA\%20UMUTESI \%20MBA $\% 202017$.pdf? sequence $=1 \&$ is Allowed $=\mathrm{y}$ 